\title{
Myostatin regulates the production of fibroblast growth factor 23 (FGF23) in UMR106 osteoblast-like cells
}

\author{
Franz Ewendt ${ }^{1} \cdot$ Martina Feger ${ }^{2} \cdot$ Michael Föller $^{2}$ (D)
}

Received: 7 September 2020 / Revised: 1 March 2021 / Accepted: 23 March 2021/Published online: 25 April 2021

(c) The Author(s) 2021

\begin{abstract}
Myostatin is a signaling molecule produced by skeletal muscle cells (myokine) that inhibits muscle hypertrophy and has further paracrine and endocrine effects in other organs including bone. Myostatin binds to activin receptor type 2B which forms a complex with transforming growth factor- $\beta$ type I receptor (TGF- $\beta$ RI) and induces intracellular p38MAPK and NFkB signaling. Fibroblast growth factor 23 (FGF23) is a paracrine and endocrine mediator produced by bone cells and regulates phosphate and vitamin D metabolism in the kidney. P38MAPK and NFKB-dependent store-operated $\mathrm{Ca}^{2+}$ entry (SOCE) are positive regulators of FGF23 production. Here, we explored whether myostatin influences the synthesis of FGF23. Fgf23 gene expression was determined by qRT-PCR and FGF23 protein by ELISA in UMR106 osteoblast-like cells. UMR106 cells expressed activin receptor type 2A and B. Myostatin upregulated $F g f 23$ gene expression and protein production. The myostatin effect on Fgf23 was significantly attenuated by TGF- $\beta R I$ inhibitor SB431542, p38MAPK inhibitor SB202190, and NFKB inhibitor withaferin A. Moreover, SOCE inhibitor 2-APB blunted the myostatin effect on $F g f 23$. Taken together, myostatin is a stimulator of $F g f 23$ expression in UMR106 cells, an effect at least partially mediated by downstream TGF$\beta R I / p 38 M A P K$ signaling as well as NFkB-dependent SOCE.
\end{abstract}

Keywords TGF- $\beta \cdot$ p38MAPK $\cdot \mathrm{Ca}^{2+} \cdot$ Vitamin D $\cdot$ Phosphate

\section{Introduction}

Myostatin is part of a group of signaling molecules produced by skeletal muscle cells (myocytes) that are known under the name "myokines" in analogy to "cytokines" [25]. It was discovered in 1997 as a member of the TGF- $\beta$ superfamily and first named "growth differentiation factor 8 (GDF-8)" [33]. Myostatin counteracts muscle hypertrophy as mice deficient in myostatin exhibit 2-3 times more muscle mass than wildtype animals [33]. Also the Belgian Blue, cattle with a loss of function mutation in the gene encoding myostatin, is characterized by enormous muscle mass [16, 25]. Finally, mutations in the human gene encoding myostatin, which result in muscle hypertrophy, are similarly described $[25,41]$.

Michael Föller

michael.foeller@uni-hohenheim.de

1 Institute of Agricultural and Nutritional Sciences, Martin Luther University Halle-Wittenberg, 06120 Halle (Saale), Germany

2 Department of Physiology, University of Hohenheim, Garbenstraße 30, 70599 Stuttgart, Germany
In addition to myocytes, myostatin also affects bone metabolism including bone formation and osteoclastogenesis [25]. In osteocytes, myostatin upregulates sclerostin and dickkopf-related protein 1 (Dkk1) [25]. Thus, the myokine myostatin plays a role as regulatory molecule in the crosstalk between muscle and bone [25, 29].

Activin receptor type $2 \mathrm{~A}$ and $\mathrm{B}(\mathrm{ACVR} 2 \mathrm{~A} / \mathrm{B})$ are the membrane receptors for myostatin. Upon binding of myostatin, transcription factor activity of SMAD2/3 and forkhead box $\mathrm{O}(\mathrm{FOXO})$ is induced, ultimately resulting in the degradation of skeletal muscle proteins [17]. Further downstream effectors of myostatin also include p38MAPK [35].

Fibroblast growth factor 23 (FGF23) can be considered as an osteokine, a hormone mainly synthesized in the bone [25, 43]. Having classical endocrine effects, its main target organ is the kidney where it binds to a membrane receptor, which is dependent on transmembrane protein $\alpha$ Klotho [19], and inhibits the formation of calcitriol $\left(1,25(\mathrm{OH})_{2} \mathrm{D}_{3}\right.$, biologically active vitamin $\mathrm{D}_{3}$ ) by suppressing 25 -hydroxyvitamin D- $1 \alpha$-hydroxylase (encoded by CYP27B1), the renal key enzyme for $1,25(\mathrm{OH})_{2} \mathrm{D}_{3}$ synthesis. Moreover, FGF23 fosters the internalization of membrane $\mathrm{NaP}_{\mathrm{i}} \mathrm{IIa}$ (SLC34Al), 
the major $\mathrm{Na}^{+}$-dependent phosphate cotransporter in the proximal tubule of the kidney, thereby increasing the urinary excretion of phosphate [20,39].

FGF23 may also be produced locally by other cells including hepatocytes [32] or cardiomyocytes thus exerting additional paracrine effects [28]. Thus, it was shown that FGF23 affects cardiac muscle and induces left ventricular hypertrophy [12], which underlines that this bone-derived molecule participates in the cross-talk between bone and muscle [25].

Moreover, the plasma concentration of FGF23 goes up in many acute and chronic diseases, notably renal and cardiovascular disorders [3, 21, 42]. Interestingly, myostatin is also upregulated in an early stage of chronic kidney diseases (CKD) [46]. Whether FGF23 is only a disease biomarker or actively drives pathophysiological processes is not entirely clear, yet [42].

The regulation of the production of FGF23 is subject to current research. Well-established regulators of FGF23 include $1,25(\mathrm{OH})_{2} \mathrm{D}_{3}$ [31], dietary phosphate [44], parathyroid hormone [27], pro-inflammatory cytokines and pathways [8, 14], interleukin-6 (IL-6) [7], erythropoietin [5, 18], iron metabolism [6], transforming growth factor (TGF) $-\beta$ (TGF- $\beta$ ) [13], peroxisome proliferator-activated receptor $\alpha$ [11], and intracellular signaling cascades including AMPdependent protein kinase (AMPK) [15] and insulin/IGF1-dependent phosphoinositide 3-kinase/Akt/FOXO signaling [2]. Remarkably, myostatin downstream signaling effector p38MAPK also controls $F g f 23$ gene expression [10].

Some human diseases with enhanced myostatin plasma levels including dermatomyositis and CKD are characterized by enhanced FGF23 production [23, 46]. This and the wellestablished muscle and bone cross-talk [25] prompted us to investigate whether myostatin directly impacts on FGF23 formation and to uncover the underlying mechanism. A direct effect could be of high relevance given that pharmacological manipulation of myostatin in disease may be a future option [25].

\section{Methods}

\section{Cell culture and treatments}

UMR106 rat osteoblast-like cells (CRL-1661; ATCC, Manassas, VA, USA) were cultured under standard conditions [13]. Per se, basal Fgf 23 expression is low in UMR 106 cells [40]. Therefore, they first have to be treated for $24 \mathrm{~h}$

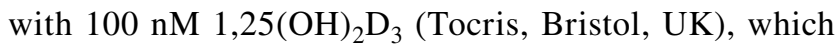
strongly enhances $F g f 23$ expression [40]. Next, cells were treated for further $24 \mathrm{~h}$ with recombinant myostatin protein (5-100 ng/mL, PeproTech, Rocky Hill, NJ, USA) in the presence or absence of TGF- $\beta$ type I receptor (TGF- $\beta$ RI) inhibitor SB431542 (10 $\mu \mathrm{M}$, Sigma-Aldrich, Schnelldorf, Germany), p38MAPK inhibitor SB202190 (10 $\mu$ M, Tocris), NFKB inhibitor withaferin A (500 nM, Tocris), or SOCE inhibitor 2-APB (150 $\mu \mathrm{M}$, Sigma).

IDG-SW3 mouse osteocytes (CVCL_0P23; Kerafast, Boston, MA, USA) were plated on rat tail type I collagen-coated 12 -well plates $(150,000$ cells per well) in $\alpha$-Minimum Essential Medium ( $\alpha$-MEM) supplemented with $10 \%$ fetal bovine serum (FBS), $100 \mathrm{U} / \mathrm{mL}$ penicillin, $100 \mu \mathrm{g} / \mathrm{mL}$ streptomycin, and $50 \mathrm{U} / \mathrm{mL}$ interferon (IFN)- $\gamma$ (all reagents from Gibco, Life Technologies, Darmstadt, Germany). Cells were grown for $24 \mathrm{~h}$ at $33{ }^{\circ} \mathrm{C}$ and $5 \%$ $\mathrm{CO}_{2}$. Next, differentiation was induced by replacing IFN- $\gamma$ with $50 \mu \mathrm{g} / \mathrm{ml}$ ascorbic acid (Sigma-Aldrich) and $4 \mathrm{mM}$ $\beta$-glycerophosphate (AppliChem, Darmstadt, Germany) and further incubation at $37{ }^{\circ} \mathrm{C}$ and $5 \% \mathrm{CO}_{2}$. The medium was changed every 2 nd to 3 rd day. At day 28, cells were incubated with $100 \mathrm{ng} / \mathrm{mL}$ recombinant myostatin or vehicle in duplicate for $8 \mathrm{~h}$.

MC3T3-E1 Subclone 4 mouse pre-osteoblast cells (CRL2593; ATCC) were cultured in $\alpha$-MEM with $2 \mathrm{mM} \mathrm{L-glu-}$ tamine, nucleosides (Gibco, Life Technologies), 10\% FBS, $100 \mathrm{U} / \mathrm{mL}$ penicillin, and $100 \mu \mathrm{g} / \mathrm{mL}$ streptomycin. They were studied from passages 23 to 27 . To this end, cells were seeded on rat tail type I collagen-coated 12 -well plates $(80,000$ cells per well) for $24 \mathrm{~h}$ and incubated with $50 \mu \mathrm{g} / \mathrm{mL}$ ascorbic acid, and $4 \mathrm{mM} \beta$-glycerophosphate for 6 days. Then, $100 \mathrm{ng} /$ $\mathrm{mL}$ myostatin or vehicle only was added in the presence of $1,25(\mathrm{OH})_{2} \mathrm{D}_{3}(10 \mathrm{nM}) 24 \mathrm{~h}$ before harvesting the cells.

\section{Quantitative real-time polymerase chain reaction}

Total RNA was isolated with TriFast reagent (Peqlab, Erlangen, Germany), and $1.2 \mu \mathrm{g}$ was used along with random primers and the GoScript ${ }^{\mathrm{TM}}$ Reverse Transcription System (Promega, Mannheim, Germany) for cDNA synthesis (program: $25^{\circ} \mathrm{C}$ for $5 \mathrm{~min}, 42^{\circ} \mathrm{C}$ for $1 \mathrm{~h}$, and $70{ }^{\circ} \mathrm{C}$ for $15 \mathrm{~min}$ ). Quantitative real-time polymerase chain reaction (qRT-PCR) using the Rotor-Gene Q cycler (Qiagen, Hilden, Germany) and GoTaq qPCR Master Mix (Promega) was performed. The amplification conditions for analysis of $\mathrm{Fgf} 23$ and TATA box-binding protein ( $\mathrm{Tbp}$ ) were $95^{\circ} \mathrm{C}$ for $3 \mathrm{~min}, 40$ cycles of $95{ }^{\circ} \mathrm{C}$ for $10 \mathrm{~s}, 57^{\circ} \mathrm{C}$ for $30 \mathrm{~s}, 72^{\circ} \mathrm{C}$ for $30 \mathrm{~s}$ (in UMR 106 cells), and $95{ }^{\circ} \mathrm{C}$ for $3 \mathrm{~min}, 40$ cycles of $95^{\circ} \mathrm{C}$ for $10 \mathrm{~s}, 58^{\circ} \mathrm{C}$ for $30 \mathrm{~s}(F g f 23)$, and $60{ }^{\circ} \mathrm{C}$ for $30 \mathrm{~s}(\mathrm{Tbp}), 72{ }^{\circ} \mathrm{C}$ for $30 \mathrm{~s}$ (in IDG-SW3 and MC3T3-E1 cells). QRT-PCR conditions for analysis of Acvr2a and Acvr2b expression in UMR106, IDG-SW3, and MC3T3-E1 cells were $95{ }^{\circ} \mathrm{C}$ for $3 \mathrm{~min}, 40$ cycles of $95{ }^{\circ} \mathrm{C}$ for $10 \mathrm{~s}, 60{ }^{\circ} \mathrm{C}$ for $30 \mathrm{~s}$, and $72{ }^{\circ} \mathrm{C}$ for $30 \mathrm{~s}$. The calculated $F g f 23$, Acvr $2 a$, and Acvr $2 b$ mRNA transcript levels in UMR106, IDG-SW3, and MC3T3-E1 cells were normalized to the transcript levels of $T b p$. 
The Acvr2a and Acvr2b qRT-PCR products of the UMR106 cells were loaded on a 1.5\% agarose gel and visualized by Midori Green.

The following primers $\left(5^{\prime} \rightarrow 3^{\prime}\right.$ orientation) were used:

Rat Acvr2a:

F: CAATATCTCACAGGGACATC,

R: TTTGGAAGTTTATAGCACCC;

Rat Acvr2b:

F: AACATCATCACGTGGAAC,

R: AACATTCTTGCTTTTGAAGTC;

Rat Fgf23:

F: TAGAGCCTATTCAGACACTTC,

R: CATCAGGGCACTGTAGATAG;

Rat Tbp:

F: ACTCCTGCCACACCAGCC,

R: GGTCAAGTTTACAGCCAAGATTCA;

Mouse Acvr2a:

F: GGTCTCTTGGAATGAACTTTG,

R: TTACTTTTGATGTCCCTGTG;

Mouse Acvr2b:

F: ATTACCTCAAGGGGAACATC,

R: CATTCTTGCTTTTGAAGTCC;

Mouse Fgf23:

F: TCGAAGGTTCCTTTGTATGGA,

R: AGTGATGCTTCTGCGACAAGT;

Mouse Tbp:

F: CCAGACCCCACAACTCTTCC,

R: CAGTTGTCCGTGGCTCTCTT.

\section{Enzyme-linked immunosorbent assay}

UMR106 cells were cultured as described and treated with $100 \mathrm{ng} / \mathrm{mL}$ myostatin for $24 \mathrm{~h}$. The cell culture supernatant was stored at $-80^{\circ} \mathrm{C}$. C-terminal FGF23 was determined by an ELISA kit (Mouse/Rat FGF-23 (C-Term), Immuntopics, San Clemente, CA, USA) according to the manufacturer's protocol. Intact FGF23 was determined in the supernatant after its concentration by means of Sartorius Vivaspin 6 Centrifugal Concentrators (Sartorius, Göttingen, Germany), with an ELISA kit (Mouse/Rat FGF-23 (Intact), Immuntopics).

\section{Statistics}

The data are shown as arithmetic means \pm SEM, and $n$ represents the number of independent experiments. Normal distribution was tested by Shapiro-Wilk normality test. Two groups were compared by unpaired Student's $t$ test (if necessary with Welch's correction) or with Mann-Whitney- $U$-test for data not normally distributed. More than two groups were tested for significance by one-way ANOVA followed by Bonferroni's multiple comparisons test (if necessary with Welch's ANOVA followed by Dunnett's T3 multiple comparisons test). Differences were considered significant if $p<0.05$.

\section{Results}

\section{Expression of the activin type 2 receptors in UMR106 cells}

The impact of myostatin on $F g f 23$ expression was studied in UMR 106 osteoblast-like cells. Employing RT-PCR, we first investigated the expression of myostatin receptors activin type $2 \mathrm{~A}$ and B (Acvr2a and Acvr2b). As illustrated in Fig. 1, mRNA specific for receptor $A c v r 2 b$ and to a markedly lesser extent for Acvr $2 a$ could be detected in UMR 106 cells. Other cell lines used to study Fgf23 include IDG-SW3 and MC3T3-E1 cells. We used quantitative RT-PCR to compare Acvr $2 a$ and $A c v r 2 b$ expression in all three cell lines. As a result, expression of Acvr2a

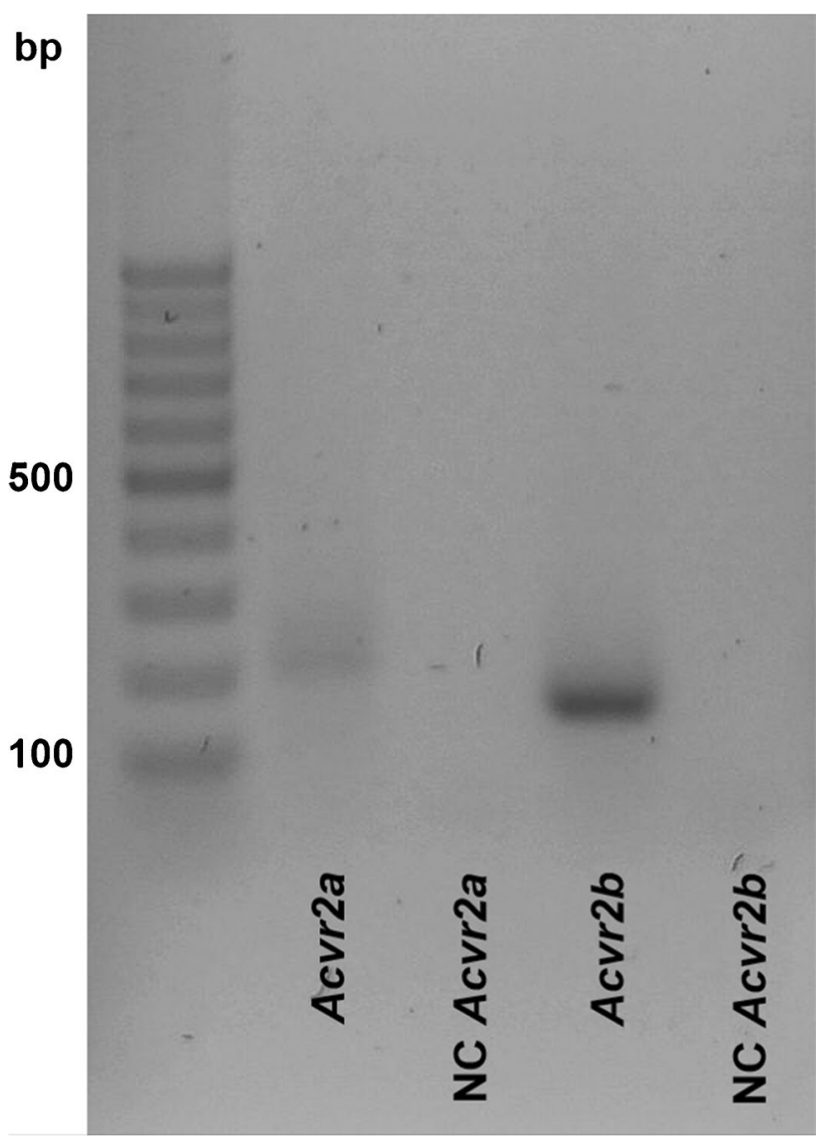

Fig. 1 Expression of activin type2 receptor isoforms in rat UMR106 osteoblast-like cells. Original agarose gel photo showing cDNA specific for activin type 2 receptor A (Acvr2a) and activin type 2 receptor B (Acvr2b) in UMR106 cells. NC, non-template control 
relative to $T b p$ was $0.0008 \pm 0.0000$ in UMR 106 cells, an expression level significantly $(p<0.001)$ lower than in IDG-SW3 cells $(0.6014 \pm 0.0615)$ and MC3T3-E1 cells $(0.2768 \pm 0.0162$; for all $n=7)$. In contrast, expression of $A c v r 2 b$ relative to $T b p$ was $0.5797 \pm 0.0465$ in UMR 106 cells, an expression level significantly $(p<0.001)$ higher than in IDG-SW3 cells $(0.0054 \pm 0.0009)$ and MC3T3-E1 cells $(0.0170 \pm 0.0017$; for all $n=7)$.

\section{Myostatin induces Fgf23 expression in UMR106 cells}

Next, we examined whether myostatin influences $\mathrm{Fgf} 23$ expression. To this end, UMR106 cells were incubated without or with different concentrations of myostatin for $24 \mathrm{~h}$ and $F g f 23$ gene expression was analyzed by quantitative RT-PCR. As shown in Fig. 2a, myostatin significantly increased $\mathrm{Fg} f 23$ gene expression in a dose-dependent manner. Using ELISA, we tested whether the stimulatory effect of myostatin on $F g f 23$ gene expression is translated into enhanced FGF23 protein secretion into the cell culture supernatant. Indeed, $24 \mathrm{~h}$ treatment with myostatin also upregulated C-terminal FGF23 (Fig. 2b) and intact FGF23 (Fig. 2c) production. In IDG-SW3 cells, an $8 \mathrm{~h}$ treatment with $100 \mathrm{ng} / \mathrm{mL}$ myostatin resulted in a relative $\mathrm{Fgf} 23$ expression of $0.0006 \pm 0.0004(n=4)$, a level not significantly different from that in control cells $(0.0006 \pm 0.0002$; $n=4)$. Similarly, a $24 \mathrm{~h}$ treatment with $100 \mathrm{ng} / \mathrm{mL}$ myostatin led to a relative $F g f 23$ expression of $0.0382 \pm 0.0025$ $(n=7)$ in MC3T3-E1 cells, a level not significantly different from that in control-treated cells $(0.0401 \pm 0.0042 ; n=7)$.

\section{Transforming growth factor- $\beta$ type I receptor is necessary for myostatin-induced $F g f 23$ expression}

The next experiments explored the signaling of the myostatin effect on $F g f 23$. The binding of myostatin to ACVR2B induces complex formation with TGF- $\beta$ RI [38]. In order to study whether this process is involved, we incubated UMR 106 cells with $100 \mathrm{ng} / \mathrm{mL}$ myostatin in the presence or absence of TGF- $\beta$ RI inhibitor SB431542 $(10 \mu \mathrm{M})$ for $24 \mathrm{~h}$. SB431542 treatment significantly abrogated myostatininduced $\mathrm{Fgf} 23$ expression in UMR106 cells (Fig. 3).

\section{The myostatin effect on Fgf 23 is at least in part dependent on P38MAPK and NFKB-mediated store-operated $\mathrm{Ca}^{2+}$ entry (SOCE)}

P38MAPK is a downstream target of myostatin [45] and also a potent regulator of FGF23 production [10]. To test whether p38MAPK contributes to the myostatin effect on Fgf 23 gene expression, UMR 106 cells were incubated with or without $100 \mathrm{ng} / \mathrm{mL}$ myostatin in the presence or absence of $10 \mu \mathrm{M}$ p38MAPK inhibitor SB202190 for $24 \mathrm{~h}$. As demonstrated in Fig. 4a, SB202190 significantly blunted myostatin-mediated upregulation of $F g f 23$ gene expression. Nevertheless, myostatin was capable of significantly enhancing $F g f 23$ gene expression even in the presence of SB202190, pointing to the involvement of further effectors. Since pro-inflammatory transcription factor complex NFKB is a powerful regulator of FGF23 and myostatin induces NFKB activity [1], we performed further experiments to elucidate an involvement of NFkB.
Fig. 2 Myostatin induces $\mathrm{Fg} 23$ expression in UMR106 cells, a Arithmetic means $\pm \mathrm{SEM}$ of relative (rel.) $F g f 23 \mathrm{mRNA}$ abundance or $\mathbf{b}$ C-terminal or $\mathbf{c}$ intact FGF23 protein concentration in the cell culture supernatant of UMR106 osteoblast-like cells incubated without (white bars) or with (black bars) myostatin (a indicated concentrations, $n=7$; and b, c $100 \mathrm{ng} /$ $\mathrm{mL}, n=10)$ for $24 \mathrm{~h}$. $* p<0.05$, $* * p<0.01$, *** $p<0.001$ indicate significant difference from control. AU, arbitrary units; ctr, control (a one-way ANOVA; b unpaired Student's $t$ test with Welch's correction; c MannWhitney- $U$-test)
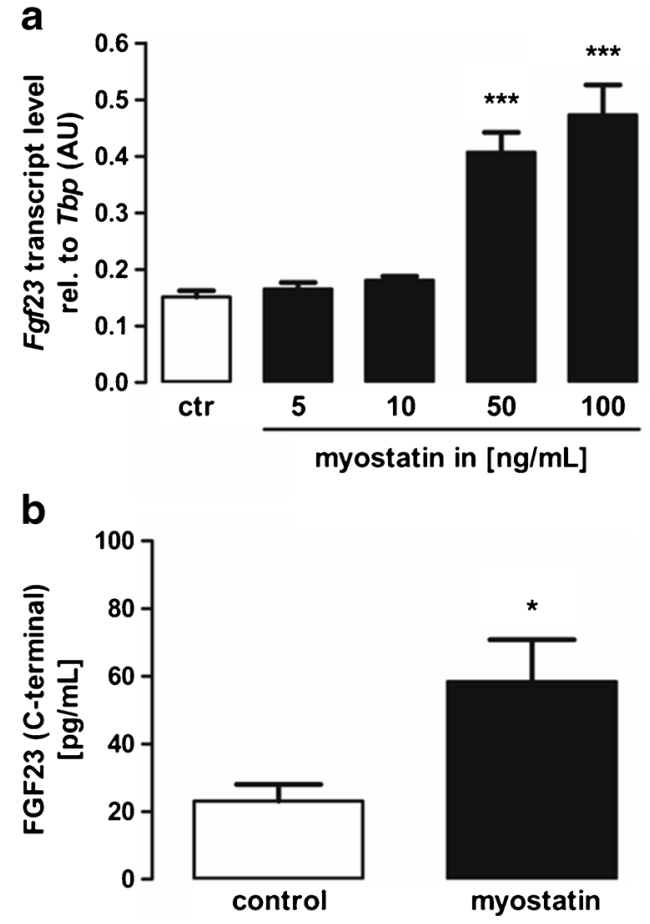

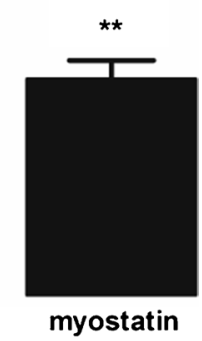




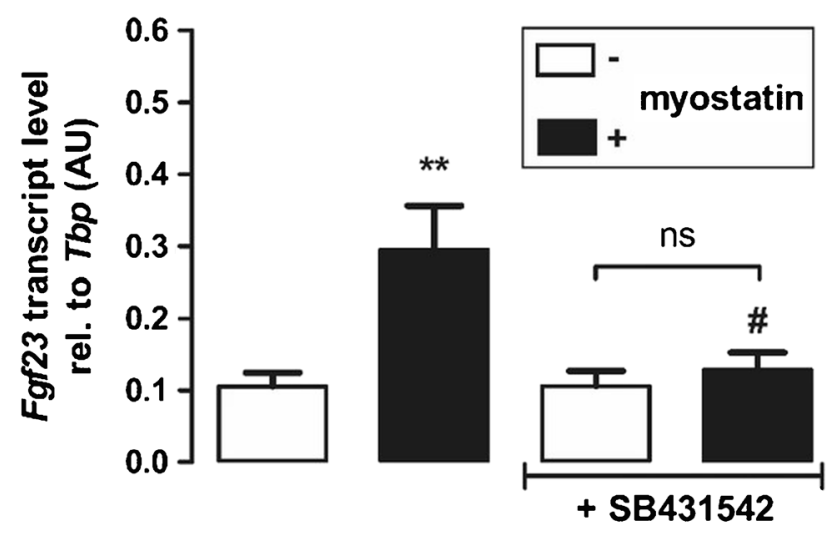

Fig. 3 Transforming growth factor- $\beta$ type I receptor (TGF- $\beta$ RI) is necessary for myostatin-induced $F g f 23$ gene expression. Arithmetic means \pm SEM of relative (rel.) Fgf 23 mRNA abundance in UMR106 osteoblast-like cells incubated without (white bars) or with (black bars) myostatin (100 ng/mL, $24 \mathrm{~h}, n=7)$ in the presence or absence of TGF- $\beta$ RI inhibitor SB431542 $(10 \mu \mathrm{M}, 24 \mathrm{~h})$. $* * p<0.01$ indicates significant difference from control. $\# p<0.05$ indicates significant difference from the absence of SB431542 (2nd vs 4th bar). AU, arbitrary units (one-way ANOVA)

To this end, UMR106 cells were treated with and without $100 \mathrm{ng} / \mathrm{mL}$ myostatin in the presence or absence of NFKB inhibitor withaferin A $(500 \mathrm{nM})$ for $24 \mathrm{~h}$. As shown in

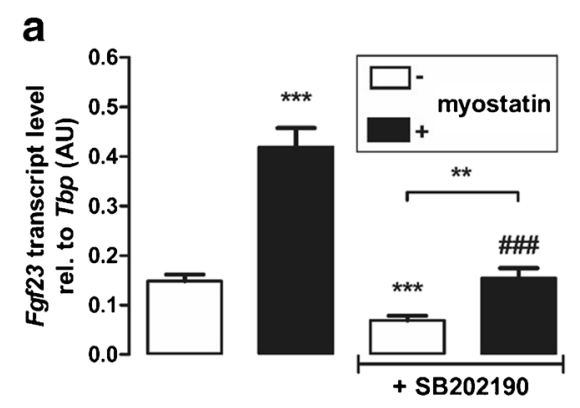

b

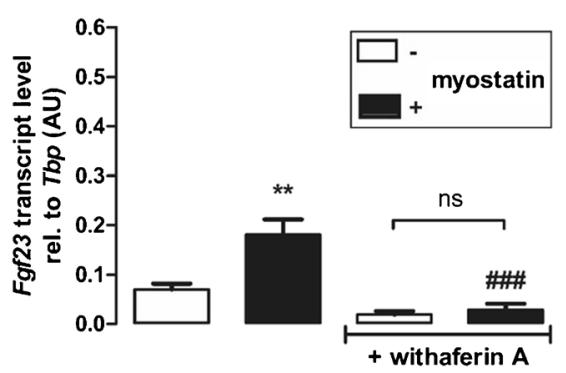

Fig. 4 The myostatin effect on Fgf23 is at least in part dependent on p38MAPK and on NFKB-mediated store-operated $\mathrm{Ca}^{2+}$ entry (SOCE). Arithmetic means \pm SEM of relative (rel.) Fgf 23 mRNA abundance in UMR106 cells treated without (white bars) or with (black bars) myostatin $(100 \mathrm{ng} / \mathrm{mL}, 24 \mathrm{~h})$ in the presence or absence of p38MAPK inhibitor SB202190 (a $10 \mu \mathrm{M}, 24 \mathrm{~h}, \mathrm{n}=16)$
Fig. 4b, myostatin did not significantly alter $F g f 23$ gene expression in the presence of withaferin A.

NFKB enhances $F g f 23$ gene expression by upregulating SOCE [47]. Hence, we sought to determine whether the myostatin effect is also dependent on SOCE. To this end, UMR106 cells were treated with or without myostatin in the presence or absence of SOCE inhibitor 2-APB $(150 \mu \mathrm{M})$ for 24 h. No significant effect of myostatin on $F g f 23$ gene expression was observed in UMR106 cells treated with 2-APB (Fig. 4c).

\section{Discussion}

This study provides evidence that myostatin, a signaling molecule produced by skeletal muscle cells, is a potent regulator of the production of FGF23, a hormone produced by bone cells. According to our results, myostatin upregulated $F g f 23$ gene expression and secretion of FGF23 protein in UMR106 osteoblast-like cells. Both, production of C-terminal and intact FGF23 were enhanced upon treatment with myostatin, suggesting that the myokine indeed regulates biologically active FGF23.

Myostatin was discovered as a myokine with mainly paracrine effects in skeletal muscle, i.e., the inhibition of skeletal muscle growth [16]. Our study adds to the growing

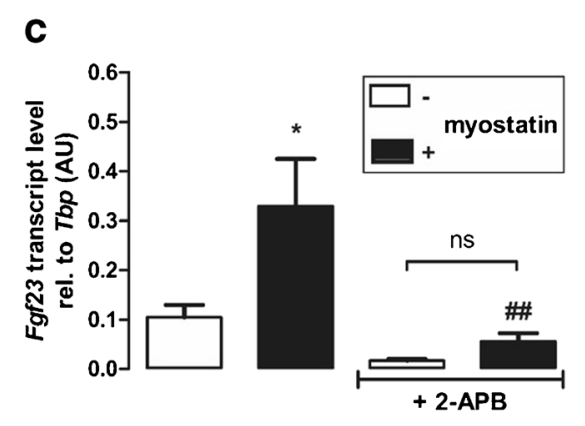

or NFkB inhibitor withaferin A (b $500 \mathrm{nM}, 24 \mathrm{~h}, \mathrm{n}=6$ ), or SOCE inhibitor 2-APB (c $150 \mu \mathrm{M}, 24 \mathrm{~h}, \mathrm{n}=6)$. $* \mathrm{p}<0.05$, **p $<0.01$, and $* * * \mathrm{p}<0.001$ indicate significant difference from control. \#\#p $<0.01$ and \#\#\#p $<0.001$ indicate significant difference from the absence of a SB202190; b withaferin A, or c 2-APB (2nd vs 4th bar). AU, arbitrary units (a Welch's ANOVA; b, c one-way ANOVA) 
concept of a muscle-bone cross-talk and further supports the notion of myostatin having paracrine and endocrine effects [25]. In this respect, it shares similarity with FGF23 which is also characterized by both paracrine and endocrine effects in different tissues and cells [28]. Other factors involved in this cross-talk are, among others, irisin, receptor activator of NF- $\kappa B$ ligand (RANKL), osteocalcin, sclerostin, or TGF- $\beta[25,29]$. The regulation of bone-derived FGF23 through muscle-derived myostatin according to our study again underlines the mutual influence of bone and muscle. Interestingly, also IL- 6 and TGF- $\beta$, other factors involved in bone-muscle cross-talk, are potent regulators of FGF23 [7, 13]. Conversely, bone-derived FGF 23 also acts on skeleton muscle, inducing muscle atrophy $[24,29]$

Our experiments also addressed the cellular mechanisms through which myostatin exerts its stimulatory effect on FGF23. The main membrane receptor for myostatin, ACVR2B [25, 38], was strongly expressed in UMR106 cells, whereas the expression level of ACVR2A was markedly lower. Conversely, expression of ACVR2B was low and that of ACVR2A was high in IDG-SW3 and MC3T3-E1 cells. Interestingly, myostatin failed to significantly affect $F g f 23$ expression in these cells, a result in line with ACVR2B being the major mediator of the myostatin effect on FGF23. Moreover, our results suggest that TGF- $\beta R I$ is involved, as TGF- $\beta R I$ inhibitor SB431542 significantly attenuated the myostatin effect on $F g f 23$. In line with a decisive role of TGF- $\beta$ RI signaling for the production of FGF23, an earlier study identified TGF- $\beta$ as a major trigger of FGF23 formation [13].

Downstream intracellular effectors of myostatin include p38MAPK [45]. Using p38MAPK inhibitor SB202190, we could demonstrate that also the myostatin effect on FGF23 is, at least in part, dependent on p38MAPK. This finding corroborates another study showing that $\mathrm{p} 38 \mathrm{MAPK}$ signaling is a regulator of FGF23, in part through pro-inflammatory transcription factor complex NFKB [10]. Importantly, $\mathrm{NF \kappa B}$ is a downstream target of myostatin [1] and itself is an important mediator of the stimulatory effect of inflammation and pro-inflammatory cytokines on FGF23 synthesis [22, 47]. NFKB is effective through inducing SOCE [47]. In line with this, both, NFKB and SOCE inhibition, significantly prevented myostatin from upregulating $F g f 23$ gene expression. A summary of the putative signaling is presented in Fig. 5.

Myostatin not only prevents muscle hypertrophy but also an increase in bone mass as myostatin deficiency results in higher bone mass [9], bone mineral density and mineral content [34]. In line with this, myostatin inhibits osteoblast differentiation [37]. FGF23 induces a reduction of the plasma phosphate and $1,25(\mathrm{OH})_{2} \mathrm{D}_{3}$ concentration. Both effects are expected to favor a reduction in bone mineralization and mass [3]. Hence, the stimulatory effect of myostatin on

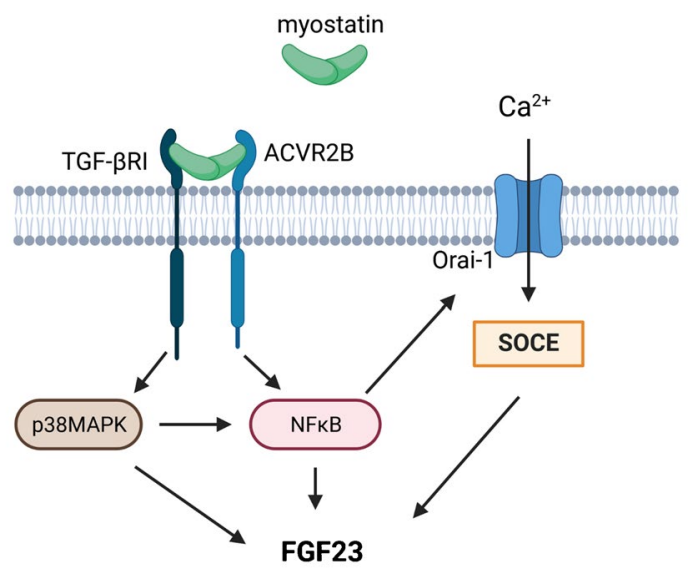

Fig. 5 Schematic illustration of myostatin-induced FGF23 production in UMR106 cells. Myostatin binding to ACVR2B and following part-

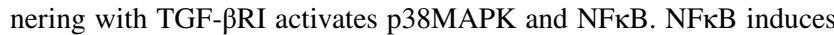
SOCE, resulting in induction of $F g f 23$ gene expression. Created with BioRender.com. Activin type 2 receptor B (ACVR2B); fibroblast growth factor 23 (FGF23); nuclear factor kappa-light-chain-enhancer of activated B-cells (NFKB); p38 mitogen-activated protein kinase (p38MAPK); store-operated $\mathrm{Ca}^{2+}$ entry (SOCE); transforming growth factor- $\beta$ type I receptor (TGF- $\beta$ RI)

FGF23 fits well into the concept of myostatin limiting skeletal muscle and bone mass.

In dermatomyositis, an inflammatory condition, the plasma myostatin concentration is elevated [23]. Importantly, the same study also found higher FGF23 levels in patients with dermatomyositis [23]. Moreover, CKD, another disease associated with elevated FGF23 levels [26], is characterized by a higher myostatin plasma concentration [46] and enhanced myostatin expression in muscle of mice [48]. These results are in line with our major finding, i.e., myostatin-dependent stimulation of FGF23 production.

Pharmacological manipulation of myostatin has already been tested as a therapeutic approach [25]: Myostatin inhibition may theoretically be beneficial in diseases with muscle weakness such as Duchenne muscular dystrophy or rheumatoid arthritis and was already tested [25]. According to our study, myostatin inhibition could result in lower FGF23, which may indeed be beneficial with regard to the reduced bone mass typical of both Duchenne muscular atrophy [4] and rheumatoid arthritis [30].

Data on the in vivo relevance of our in vitro results are sparse thus far: No gross differences in serum $\mathrm{Ca}^{2+}$ or phosphate were reported in Holstein Friesian calves and Belgian Blue calves [36]. Clearly, further in vivo studies exploring FGF23 and phosphate metabolism in myostatin-deficient mice or in Belgian Blue cattle are needed to confirm the significance of our findings.

Taken together, this study found a direct stimulatory effect of myostatin on $F g f 23$ gene expression and protein 
production in UMR106 cells. Moreover, it uncovered that this effect is, at least in part, mediated by p38MAPK and $\mathrm{NF \kappa B}$. These findings may contribute to higher FGF23 levels in some diseases with enhanced myostatin production and may be relevant for future therapeutic approaches involving pharmacological manipulation of myostatin.

Acknowledgements The authors thank S. Ross, F. Reipsch, S. Münz, and $\mathrm{H}$. Froß for technical help.

Author contribution F. Ewendt and M. Föller designed the research; F. Ewendt analyzed the data; F. Ewendt and M. Feger performed the research; and M. Föller, F. Ewendt, and M. Feger wrote the paper.

Funding Open Access funding enabled and organized by Projekt DEAL. This study was supported by the Deutsche Forschungsgemeinschaft.

Data Availability. Data and material will be shared.

Code availability. Not applicable.

\section{Declarations}

Ethics approval Not applicable.

Consent to participate. Not applicable.

Consent for publication. Not applicable.

Competing interests The authors declare no competing interests.

Open Access This article is licensed under a Creative Commons Attribution 4.0 International License, which permits use, sharing, adaptation, distribution and reproduction in any medium or format, as long as you give appropriate credit to the original author(s) and the source, provide a link to the Creative Commons licence, and indicate if changes were made. The images or other third party material in this article are included in the article's Creative Commons licence, unless indicated otherwise in a credit line to the material. If material is not included in the article's Creative Commons licence and your intended use is not permitted by statutory regulation or exceeds the permitted use, you will need to obtain permission directly from the copyright holder. To view a copy of this licence, visit http://creativecommons.org/licenses/by/4.0/.

\section{References}

1. Aravena J, Abrigo J, Gonzalez F et al (2020) Angiotensin (1-7) Decreases myostatin-induced NF- $\mathrm{kB}$ signaling and skeletal muscle atrophy. Int J MolSci 21:1167. https://doi.org/10.3390/ijms2 1031167

2. Bär L, Feger M, Fajol A et al (2018) Insulin suppresses the production of fibroblast growth factor 23 (FGF23). Proc Natl Acad Sci U S A 115:5804-5809. https://doi.org/10.1073/pnas.18001 60115

3. Bär L, Stournaras C, Lang F et al (2019) Regulation of fibroblast growth factor 23 (FGF23) in health and disease. FEBS Lett 593:1879-1900. https://doi.org/10.1002/1873-3468.13494
4. Buckner JL, Bowden SA, Mahan JD (2015) Optimizing bone health in Duchenne muscular dystrophy. Int J Endocrinol 2015:928385. https://doi.org/10.1155/2015/928385

5. Daryadel A, Bettoni C, Haider T et al (2018) Erythropoietin stimulates fibroblast growth factor 23 (FGF23) in mice and men. Pflugers Arch 470:1569-1582. https://doi.org/10.1007/ s00424-018-2171-7

6. David V, Martin A, Isakova T et al (2016) Inflammation and functional iron deficiency regulate fibroblast growth factor 23 production. Kidney Int 89:135-146. https://doi.org/10.1038/ki.2015.290

7. Durlacher-Betzer K, Hassan A, Levi R et al (2018) Interleukin-6 contributes to the increase in fibroblast growth factor 23 expression in acute and chronic kidney disease. Kidney Int 94:315-325. https://doi.org/10.1016/j.kint.2018.02.026

8. Egli-Spichtig D, Imenez Silva PH, Glaudemans B et al (2019) Tumor necrosis factor stimulates fibroblast growth factor 23 levels in chronic kidney disease and non-renal inflammation. Kidney Int 96:890-905. https://doi.org/10.1016/j.kint.2019.04.009

9. Elkasrawy MN, Hamrick MW (2010) Myostatin (GDF-8) as a key factor linking muscle mass and bone structure. J Musculoskelet Neuronal Interact 10:56-63

10. Ewendt F, Föller M (2019) p38MAPK controls fibroblast growth factor 23 (FGF23) synthesis in UMR106-osteoblast-like cells and in IDG-SW3 osteocytes. J Endocrinol Invest 42:1477-1483. https://doi.org/10.1007/s40618-019-01073-y

11. Ewendt F, Hirche F, Feger M et al (2020) Peroxisome proliferator-activated receptor $\alpha(\mathrm{PPAR} \alpha)$-dependent regulation of fibroblast growth factor 23 (FGF23). Pflugers Arch 472:503-511. https://doi.org/10.1007/s00424-020-02363-8

12. Faul C, Amaral AP, Oskouei B et al (2011) FGF23 induces left ventricular hypertrophy. J Clin Invest 121:4393-4408. https:// doi.org/10.1172/JCI46122

13. Feger M, Hase P, Zhang B et al (2017) The production of fibroblast growth factor 23 is controlled by TGF- $\beta 2$. Sci Rep 7:4982. https://doi.org/10.1038/s41598-017-05226-y

14. Francis C, David V (2016) Inflammation regulates fibroblast growth factor 23 production. Curr Opin Nephrol Hypertens 25:325-332. https://doi.org/10.1097/MNH.0000000000000232

15. Glosse P, Feger M, Mutig K et al (2018) AMP-activated kinase is a regulator of fibroblast growth factor 23 production. Kidney Int 94:491-501. https://doi.org/10.1016/j.kint. 2018.03.006

16. Grobet L, Martin LJ, Poncelet D et al (1997) A deletion in the bovine myostatin gene causes the double-muscled phenotype in cattle. Nat Genet 17:71-74. https://doi.org/10.1038/ng0997-71

17. Han HQ, Zhou X, Mitch WE et al (2013) Myostatin/activin pathway antagonism: molecular basis and therapeutic potential. Int J Biochem Cell Biol 45:2333-2347. https://doi.org/10. 1016/j.biocel.2013.05.019

18. Hanudel MR, Eisenga MF, Rappaport M et al (2019) Effects of erythropoietin on fibroblast growth factor 23 in mice and humans. Nephrol Dial Transplant 34:2057-2065. https://doi.org/ 10.1093/ndt/gfy 189

19. Hu MC, Shi M, Moe OW (2019) Role of $\alpha$ Klotho and FGF23 in regulation of type II Na-dependent phosphate co-transporters. Pflugers Arch 471:99-108. https://doi.org/10.1007/ s00424-018-2238-5

20. Indirli R, Guabello G, Longhi M et al (2020) FGF23-related hypophosphatemia in patients with low bone mineral density and fragility fractures: challenges in diagnosis and management. J Endocrinol Invest 43:787-798. https://doi.org/10.1007/ s40618-019-01165-9

21. Isakova T, Cai X, Lee J et al (2018) Longitudinal FGF23 trajectories and mortality in patients with CKD. J Am Soc Nephrol 29:579-590. https://doi.org/10.1681/ASN.2017070772 
22. Ito N, Wijenayaka AR, Prideaux M et al (2015) Regulation of FGF23 expression in IDG-SW3 osteocytes and human bone by pro-inflammatory stimuli. Mol Cell Endocrinol 399:208-218. https://doi.org/10.1016/j.mce.2014.10.007

23. Kerschan-Schindl K, Gruther W, Föger-Samwald U et al (2021) Myostatin and markers of bone metabolism in dermatomyositis. BMC Musculoskelet Disord 22:150. https://doi.org/10.1186/ s12891-021-04030-0

24. Kido S, Hashimoto Y, Segawa $\mathrm{H}$ et al (2012) Muscle atrophy in patients wirh ckd results from fgf23/klotho-mediated supression of insulin/igf-i signaling. Kidney Research and Clinical Practice 31:A44. https://doi.org/10.1016/j.krcp.2012.04.435

25. Lara-Castillo N, Johnson ML (2020) Bone-muscle mutual interactions. Curr Osteoporos Rep. https://doi.org/10.1007/ s11914-020-00602-6

26. Larsson T, Nisbeth U, Ljunggren O et al (2003) Circulating concentration of FGF-23 increases as renal function declines in patients with chronic kidney disease, but does not change in response to variation in phosphate intake in healthy volunteers. Kidney Int 64:2272-2279. https://doi.org/10.1046/j.1523-1755. 2003.00328.x

27. Lavi-Moshayoff V, Wasserman G, Meir T et al (2010) PTH increases FGF23 gene expression and mediates the high-FGF23 levels of experimental kidney failure: a bone parathyroid feedback loop. Am J Physiol Renal Physiol 299:F882-F889. https://doi.org/ 10.1152/ajprenal.00360.2010

28. Leifheit-Nestler M, Haffner D (2018) Paracrine effects of FGF23 on the heart. Front Endocrinol (Lausanne) 9:278. https://doi.org/ 10.3389/fendo.2018.00278

29. Li G, Zhang L, Wang D et al (2019) Muscle-bone crosstalk and potential therapies for sarco-osteoporosis. J Cell Biochem 120:14262-14273. https://doi.org/10.1002/jcb.28946

30. Lodder MC, de Jong Z, Kostense PJ et al (2004) Bone mineral density in patients with rheumatoid arthritis: relation between disease severity and low bone mineral density. Ann Rheum Dis 63:1576-1580. https://doi.org/10.1136/ard.2003.016253

31. Masuyama R, Stockmans I, Torrekens S et al (2006) Vitamin D receptor in chondrocytes promotes osteoclastogenesis and regulates FGF23 production in osteoblasts. J Clin Invest 116:3150 3159. https://doi.org/10.1172/JCI29463

32. Mattinzoli D, Ikehata M, Tsugawa K et al (2018) FGF23 and Fetuin-A interaction in the liver and in the circulation. Int $\mathrm{J}$ Biol Sci 14:586-598. https://doi.org/10.7150/ijbs.23256

33. McPherron AC, Lawler AM, Lee SJ (1997) Regulation of skeletal muscle mass in mice by a new TGF-beta superfamily member. Nature 387:83-90. https://doi.org/10.1038/387083a0

34. Morissette MR, Stricker JC, Rosenberg MA et al (2009) Effects of myostatin deletion in aging mice. Aging Cell 8:573-583. https:// doi.org/10.1111/j.1474-9726.2009.00508.x

35. Philip B, Lu Z, Gao Y (2005) Regulation of GDF-8 signaling by the p38 MAPK. Cell Signal 17:365-375. https://doi.org/10.1016/j. cellsig.2004.08.003

36. Probo M, Giordano A, Moretti P et al (2019) Serum biochemical profile in Holstein Friesian and Belgian blue calves in the first 48 hours of life. Ital J Anim Sci 18:657-662. https://doi.org/10.1080/ 1828051X.2018.1551073

37. Qin Y, Peng Y, Zhao W et al (2017) Myostatin inhibits osteoblastic differentiation by suppressing osteocyte-derived exosomal microRNA-218: a novel mechanism in muscle-bone communication. J Biol Chem 292:11021-11033. https://doi.org/10.1074/jbc. M116.770941

38. Rebbapragada A, Benchabane H, Wrana JL et al (2003) Myostatin signals through a transforming growth factor beta-like signaling pathway to block adipogenesis. Mol Cell Biol 23:7230-7242. https://doi.org/10.1128/mcb.23.20.7230-7242.2003

39. Rodríguez-Ortiz ME, Rodríguez M (2015) FGF23 as a calciotropic hormone. F1000Res 4:1472. https://doi.org/10.12688/f1000 research.7189.1

40. Saini RK, Kaneko I, Jurutka PW et al (2013) 1,25-dihydroxyvitamin $\mathrm{D}(3)$ regulation of fibroblast growth factor-23 expression in bone cells: evidence for primary and secondary mechanisms modulated by leptin and interleukin-6. Calcif Tissue Int 92:339353. https://doi.org/10.1007/s00223-012-9683-5

41. Schuelke M, Wagner KR, Stolz LE et al (2004) Myostatin mutation associated with gross muscle hypertrophy in a child. N Engl J Med 350:2682-2688. https://doi.org/10.1056/NEJMoa040933

42. Stöhr R, Schuh A, Heine GH et al (2018) FGF23 in cardiovascular disease: innocent bystander or active mediator? Front Endocrinol (Lausanne) 9:351. https://doi.org/10.3389/fendo.2018.00351

43. Takashi Y, Fukumoto S (2020) Phosphate-sensing and regulatory mechanism of FGF23 production. J Endocrinol Invest. https://doi. org/10.1007/s40618-020-01205-9

44. Vervloet MG, van Ittersum FJ, Büttler RM et al (2011) Effects of dietary phosphate and calcium intake on fibroblast growth factor-23. Clin J Am Soc Nephrol 6:383-389. https://doi.org/10. 2215/CJN.04730510

45. Wallner C, Jaurich H, Wagner JM et al (2017) Inhibition of GDF8 (Myostatin) accelerates bone regeneration in diabetes mellitus type 2. Sci Rep 7:9878. https://doi.org/10.1038/ s41598-017-10404-z

46. Yano S, Nagai A, Isomura M et al (2015) Relationship between blood myostatin levels and kidney function: Shimane CoHRE Study. PLoS ONE 10:e0141035. https://doi.org/10.1371/journal. pone.0141035

47. Zhang B, Yan J, Umbach AT et al (2016) NFкB-sensitive Orai1 expression in the regulation of FGF23 release. J Mol Med 94:557566. https://doi.org/10.1007/s00109-015-1370-3

48. Zhang L, Rajan V, Lin E et al (2011) Pharmacological inhibition of myostatin suppresses systemic inflammation and muscle atrophy in mice with chronic kidney disease. FASEB J 25:1653-1663. https://doi.org/10.1096/fj.10-176917

Publisher's note Springer Nature remains neutral with regard to jurisdictional claims in published maps and institutional affiliations. 